\title{
Effect of Bile Salts and Acidity on the Viability of Some Lactic Acid Bacteria
}

\author{
Hoda Mahrous ${ }^{1}$, El Soda, M.A. ${ }^{2}$, El-Halfawy, K.A. ${ }^{1}$ \& Kamaly, K. M. ${ }^{3}$ \\ ${ }^{1}$ Genetic Engineering \& Biotechnology Res. Inst. (GEBRI), Menuofiya Univ., Egypt. \\ ${ }^{2}$ Dairy Science Dept., Fac. of Agric., Alex. Univ., Egypt. \\ ${ }^{3}$ Dairy Science and Technology. Dept., Fac. of Agric., Menuofiya Univ., Egypt.
}

\begin{abstract}
Probiotic microorganismis were found to affect beneficially the host by improving intestinal microbial balance. They have also many benefits such as reducing the risk of diarrhea, normalize bowel movements, enhancing immune functions, reducing cholesterol levels, reducing the risk of eczema, protection from cancer and relief of lactose intolerance symptoms.Some probiotic properties of identified strains of lactic acid bacteria (21 strains) which isolated from healthy breast-feeding infants were studied in the presence of different concentrations of bile salts $(0.2,0.3$ and $0.4 \%)$ and different values of $\mathrm{pH}(4,3$ and 2). The results as compared to control revealed that 11 strains of Lb. fermentum and all strains of $L b$. salivarius exhibited variant growth at all concentrations of bile salts. On the other hand, all strains of $L b$. fermentum and 8 strains of $L b$. salivarius were tolerant to the changing in $\mathrm{pH}$. They kept their viability at $\mathrm{pH}$ 3.0 and 4.0 .
\end{abstract}

Keywords: probiotics, bile salts, acid tolerance, Lb. salivarius, Lb. fermentum, LAB.

\section{INTRODUCTION}

During last years, numerous studies have been undertaken to obtain scientific evidences for the beneficial effects of fermented foods containing probiotic bacteria (Renault, 2002, Rafter, 2002). At the present, a large number of dairy products are presented on the market and are being promoted with health claims based on several characteristics of selected strains belonging to the genera Lactobacillus and Bifidobacterium (Shah, 2000).

To provide health benefits, the suggested concentration for probiotic bacteria is $10^{6} \mathrm{CFU} / \mathrm{g}$ of a product (Robinson, 1987). Viability and survivability of probiotic bacteria are the most important parameters in order to provide therapeutic functions. Several factors have been claimed to affect the viability of probiotic bacteria in fermented dairy foods, i.e. yoghurt and fermented milks. Moreover, the tolerance to human gastric transit constitutes an important selection criterion for probiotic bacteria (Goldin \& Gorbach, 1989, Ouwehand et al., 1999). Probiotic related microorganisms ingested with food begin subjected to successive stress factors that influence their survival (Marteau et al., 1993) during their transit through the gastrointestinal tract the time reported from entrance to release from the stomach is about 90 min (Berrada et al., 1991), but further digestive processes have longer residence times. Bacterial stress starts in the stomach juice, at $\mathrm{pH}$ as 1.5 (Lankaputhra \& Shah, 1995). Bile salts secreted in the small intestine reduce the survival of bacteria by impairment their cell membranes, whose major components are lipids and fatty acids and these modifications may affect not only the cell permeability and viability, but also the interactions between the membrane and the environment (Gilliland et al., 1984, Gilliland, 1987). Therefore before a probiotic can benefit human health it fulfills several criteria such as the ability to tolerate acid and bile salts as well as to grow in the lower intestinal tract (Hirayama \& Rafter, 2000).

So, the first tool in the selection of probiotic strains is represented by in vitro methods aiming to ascertain the ability to survive passage through the upper gastrointestinal tract and arrive alive at its site of action (Saarela et al., 2000). The present research was tailored to study the ability of $L b$. fermentum and $L b$. salivarius to grow at different bile salts concentrations and at different $\mathrm{pH}$ levels.

\section{MATERIALS AND METHODS}

\section{Test organisms}

Twenty one isolates were obtained from healthy, breast-feeding Egyptian infants (3-6 m old) and identified as follows: (12 strains) Lactobacillus fer- 
mentum, (9 strains) Lactobacillus salivarius. The strains were grown in MRS broth at $37^{\circ} \mathrm{C}$. Organisms were subcultured every $18 \mathrm{hr}$ or $14 \mathrm{hr}$ twice before experimental use. Bacterial stock cultures were stored at $-80^{\circ} \mathrm{C}$ in $15 \%(\mathrm{v} / \mathrm{v})$ glycerol.

\section{Bile tolerance}

All strains were evaluated for rapidity of growth in MRS (Biolife, Milano, Italy) broth with and without bile salts at $37^{\circ} \mathrm{C}$. Overnight cultures were inoculated $10 \%(\mathrm{v} / \mathrm{v})$ into MRS broth and MRS broth containing $0.2,0.3$ and $0.4 \%(\mathrm{w} / \mathrm{v})$ bile salts and incubated at $37^{\circ} \mathrm{C}$.

Development of bacterial growth was followed for $6 \mathrm{hr}$ by measuring the absorbance at $650 \mathrm{~nm}$ $\left(\mathrm{A}_{650 \mathrm{~nm}}\right)$ using a spectrophotometer at one hour interiors. Comparison of cultures was based on their growth rates in each broth. The experiments were conducted twice in duplicates.

\section{Acid tolerance}

Overnight cultures were previously prepared by inoculated $(0.1 \% \mathrm{v} / \mathrm{v})$ into MRS broth at $37^{\circ} \mathrm{C}$ for $16 \mathrm{hr}$ to until logarithmic phase. Cultures were inoculated $(10 \% \mathrm{v} / \mathrm{v})$ into MRS broth previously adjusted to $\mathrm{pH}(2.0,3.0$ and $4.0 \pm 0.1)$ with $\mathrm{HCl}$. The mixtures were incubated at $37^{\circ} \mathrm{C}$ and growth development was followed for $6 \mathrm{hr}$ by measuring the absorbance at $650 \mathrm{~nm}\left(\mathrm{~A}_{650 \mathrm{~nm}}\right)$ using a spectrophotometer (Pharmacia LKB NOVASPEC II). Comparison of cultures was based on their growth development in each broth and compared with MRS broth (pH 6.6) inoculated with the previous strains. The experiments were repeated two times in duplicate.

\section{RESULTS AND DISCUSSION}

\section{Bile salts tolerance}

Figures (1 and 2) show the effect of different bile salt concentrations $(0.2,0.3$ and $0.4 \% \mathrm{w} / \mathrm{v})$. Generally, bile salt concentration at $0.4 \%$, exhibited the most suppression to all $L b$. fermentum and Lb. salivarius strains as compared to control values at $6 \mathrm{hrs}$. It is noted that all strains were able to grow in the presence of $0.2 \%$ bile salts. Data in Fig. (1) show that $L b$. fermentum (5) was less bile tolerant than the other strains tested. It was clear that this strain was able to grow in the precence of bile salts but with little decrease in the growth as compared with the control. Also, the results revealed that $L b$. fermentum (1, 2, 3, 4, 6, 7, 8, 9, 10, 11 and 12) showed less difference in their growth in the media with bile salts. It was clear that the growth rate in the presence of bile salts was almost similar to the absence of bile salts.

Previous work done by Charteris et al. (1998) and Pereira \& Gibson (2002) reported that, the small intestinal transit tolerance of bile salts-resistant lactobacilli was found to be strain-dependent. The majority of strains was intrinsically resistant to simulated pancreatic juice and showed no reduction in viability for up to $4 \mathrm{hr}$. However, minorities of strains were sensitive and could be divided into tow groups: The first was characterized by complete or progressive loss of viability during exposure and was represented by strain $B$. adolescentis $15703 \mathrm{~T}$. The second was characterized by a rapid reduction in viability on exposure followed by recovery of viability during prolonged exposure and was represented by $L b$. fermintum KLD.

The results in Fig. (2) show that $L b$. salivarius $(1,2,3,4,5,6,7,8$ and 9) were more resistant than the other strains tested. It was obvious that these strains were able to grow in the presence of bile salts with little decrease in the growth as compared with control values.

Resistance to bile salts is generally considered as an essential property for probiotic strains to survive the conditions in the small intestine. The presence of bile salts in the environment of bacteria cultures is much more detrimental than effect of $\mathrm{pH} 3.0$. The choice of the bile concentration selected for our screening ( $0.4 \%$ Oxgall solution) was based on its being equivalent to the physiological concentration in the duodenum or the human bile juice (Brashears et al. 2003). Many authors investigated the effect of bile on survival of LAB. Kim et al. (1999) examined the effect of bile concentration in the range of $0-0.4 \%$ on the Lb. lactis survival and they reported inhibiting effect of bile at concentration over $0.04 \%$. They detected that all bacterial cells were killed at $0.2 \%$ and higher (Olejnik et al. 2005). Comparing to this study, our experiments showed much more resistance to detrimental actions of bile salts where the viability of strains of $L b$. plantarum and $L b$. fermentum seemed to improve when exposed to high levels of oxgall $(0.4 \%)$.

\section{Acid tolerance}

The effects of acidity on the growth of the identified strains are presented in Figs. (3 and 4). The results in Fig. (3) indicate that Lb. fermentum 


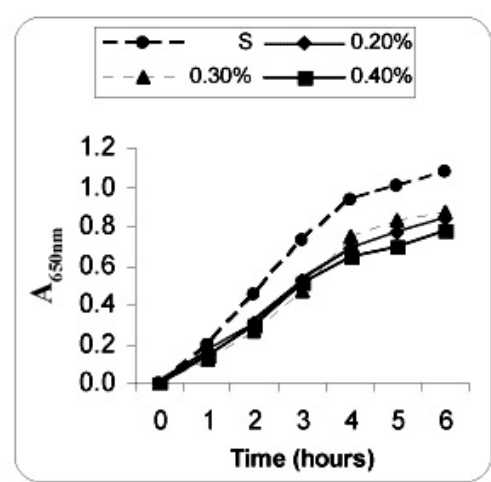

(1)

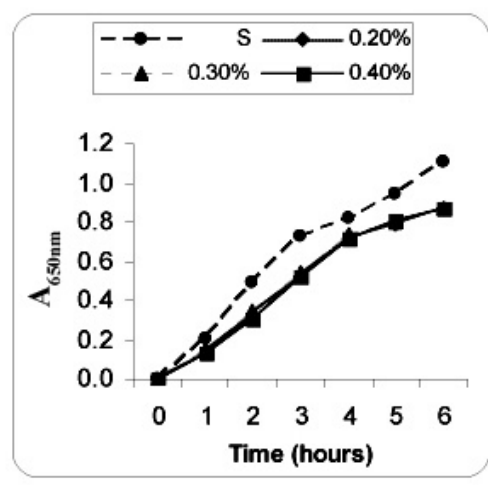

(4)

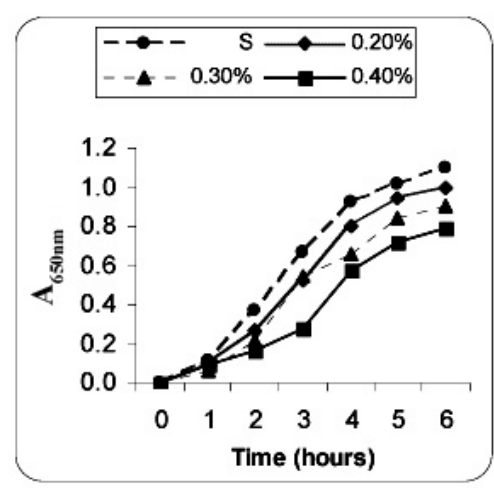

(7)

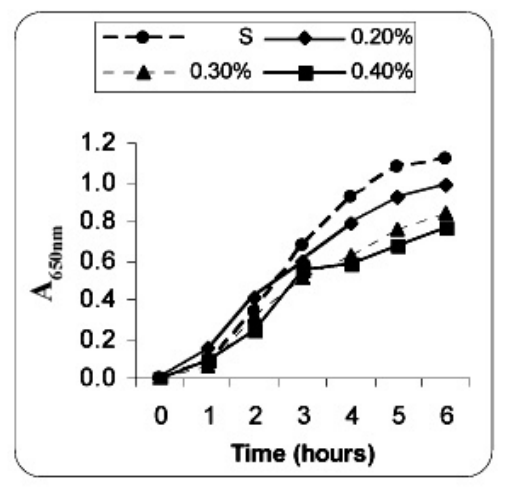

(10)

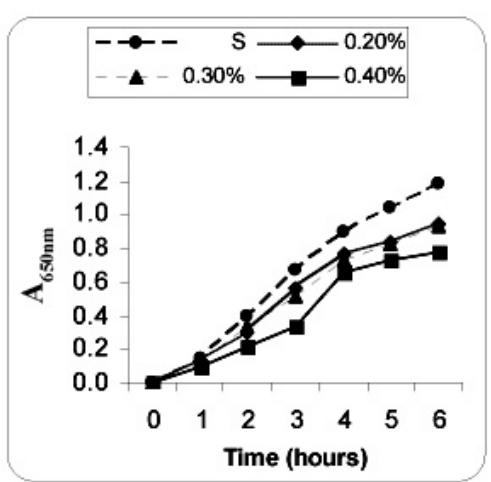

(2)

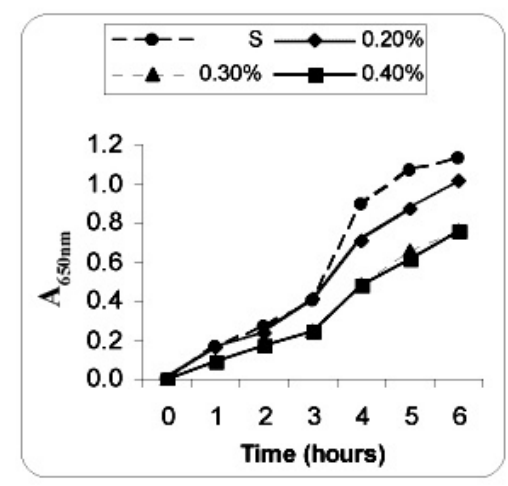

(5)

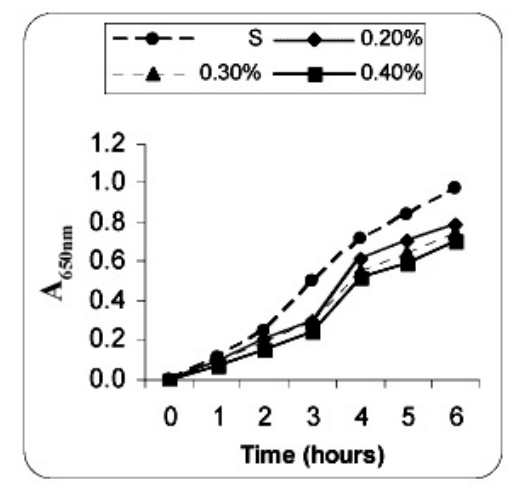

(8)

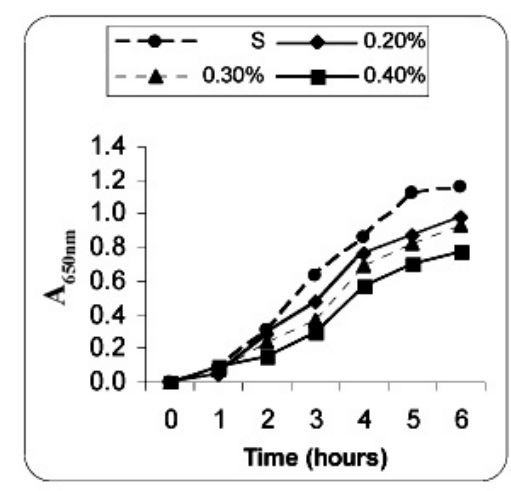

(11)

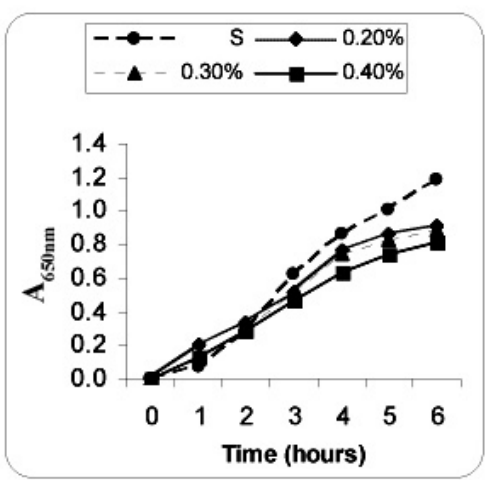

(3)

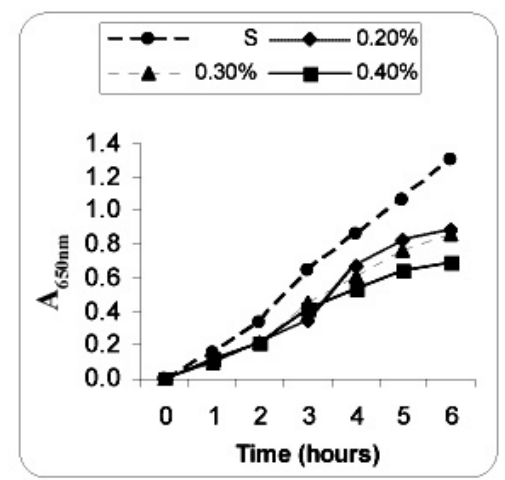

(6)

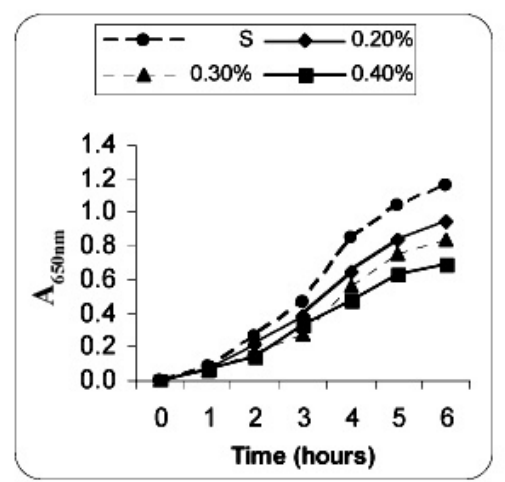

(9)

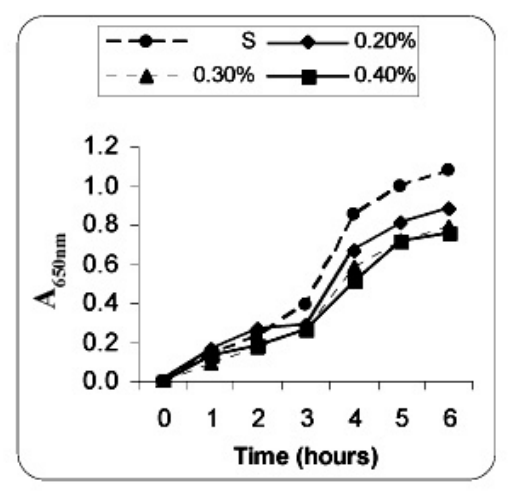

(12)

Fig. 1: Growth development of $L b$. fermentum $(1,2,3,4,5,6,7,8,9,10,11$ and 12) in standard and supplemented MRS broth with different bile salts concentrations for $6 \mathrm{hrs}$ at $37^{\circ} \mathrm{C}$ 


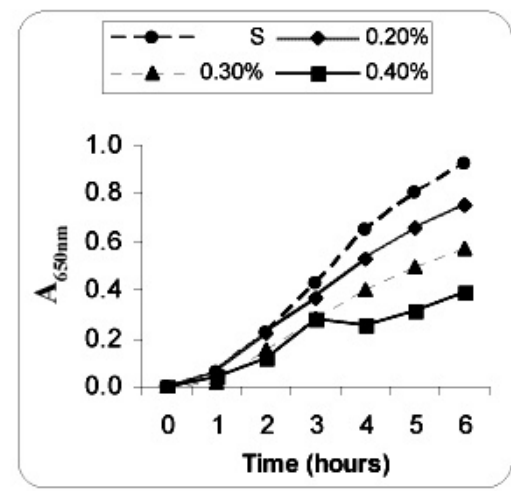

(1)

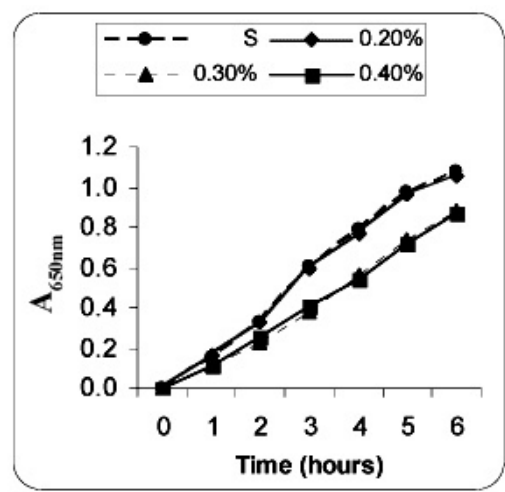

(4)

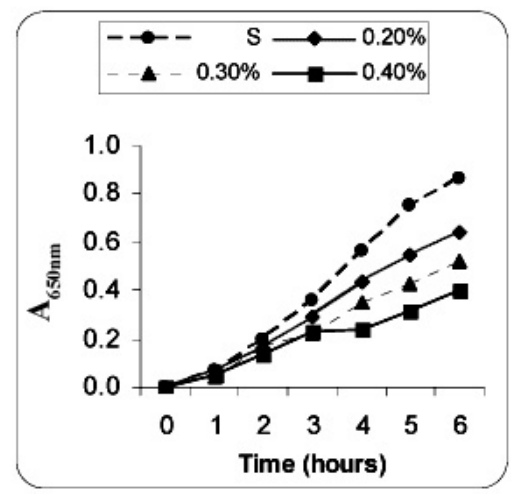

(7)

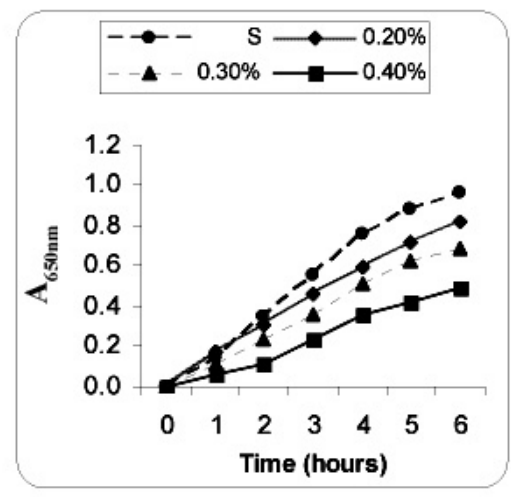

(2)

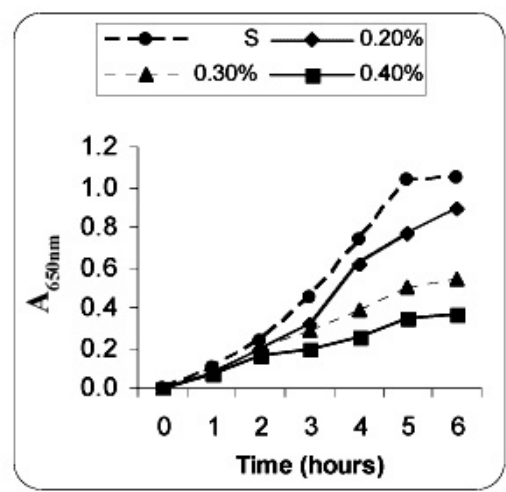

(5)

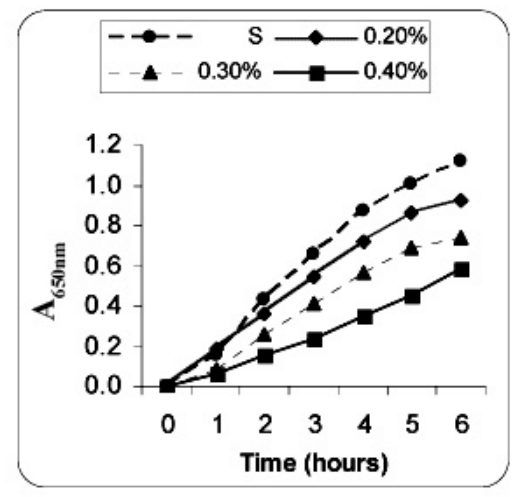

(8)

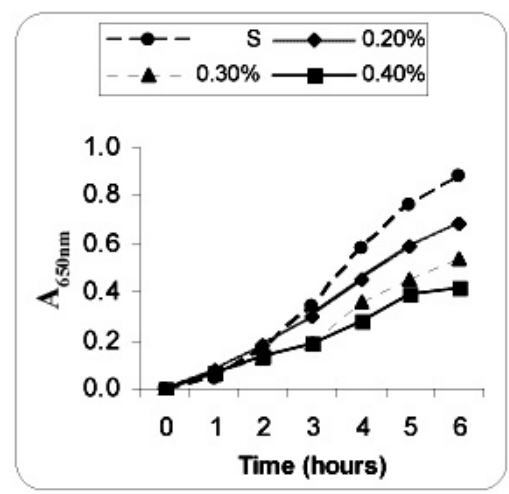

(3)

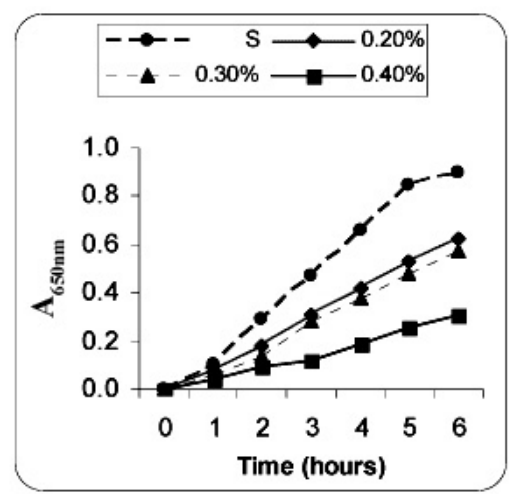

(6)

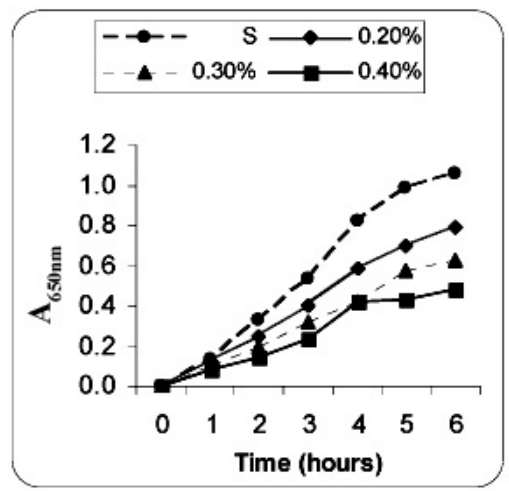

(9)

Fig. 2: Growth development of $L$ b. salivarius $(1,2,3,4,5,6,7,8$ and 9) in standard and supplemented MRS broth with different bile salts concentrations for $6 \mathrm{hrs}$ at $37^{\circ} \mathrm{C}$ 


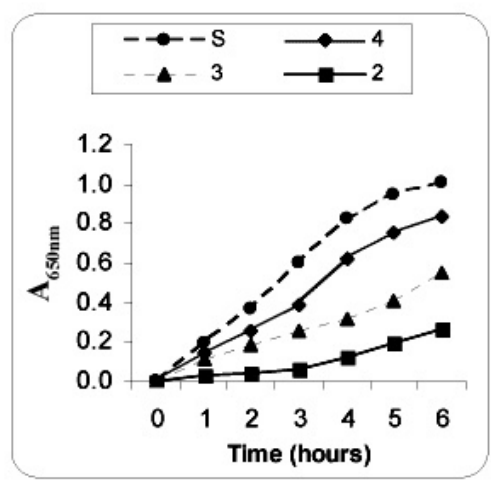

(1)

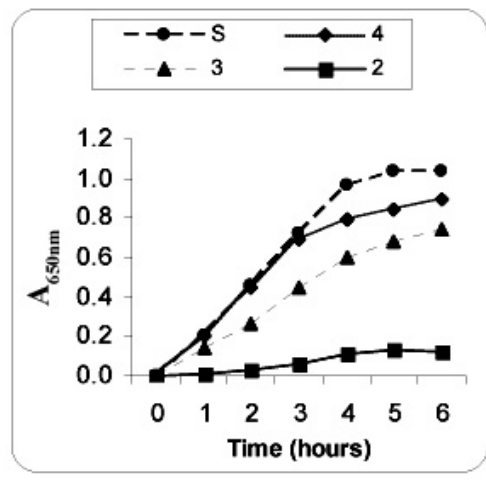

(4)

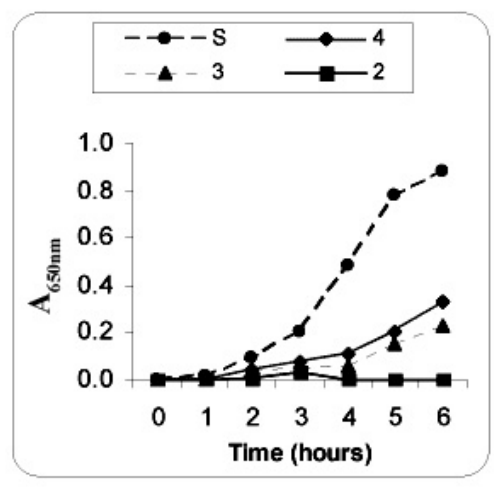

(7)

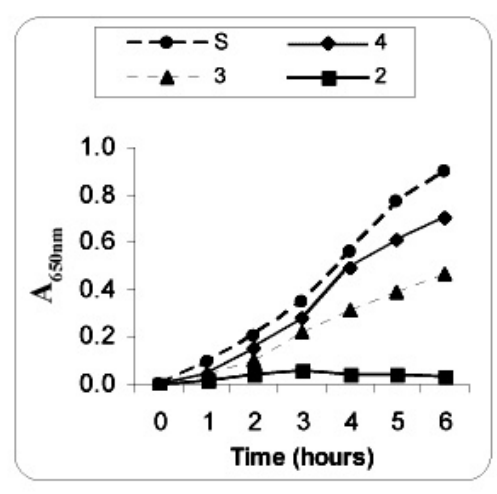

(10)

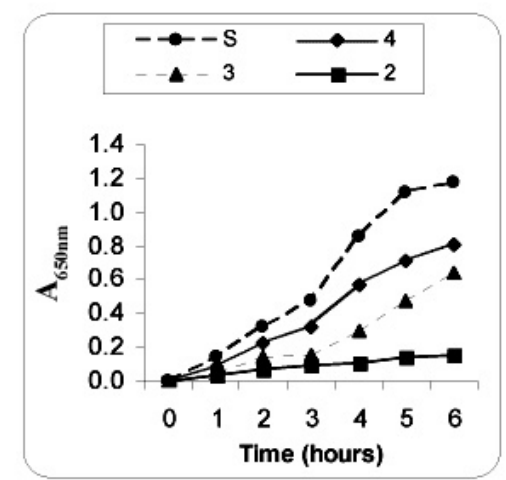

(2)

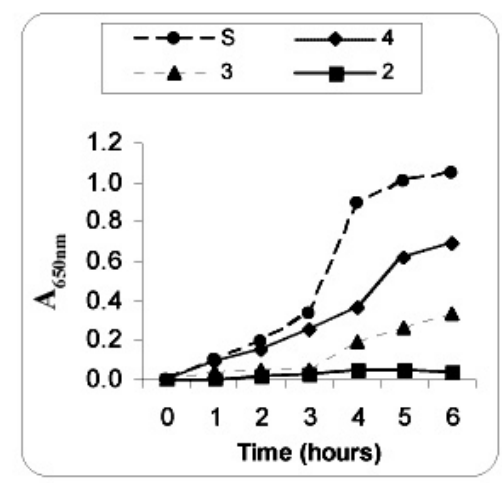

(5)

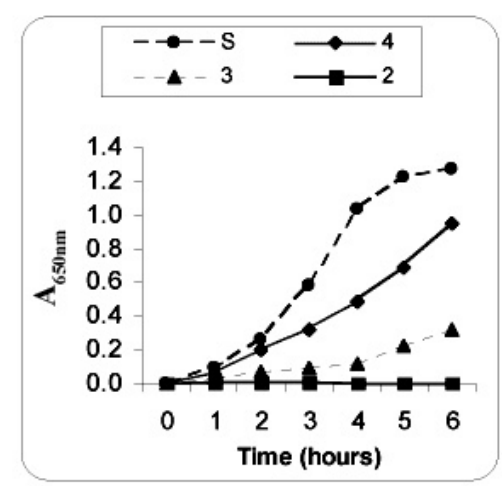

(8)

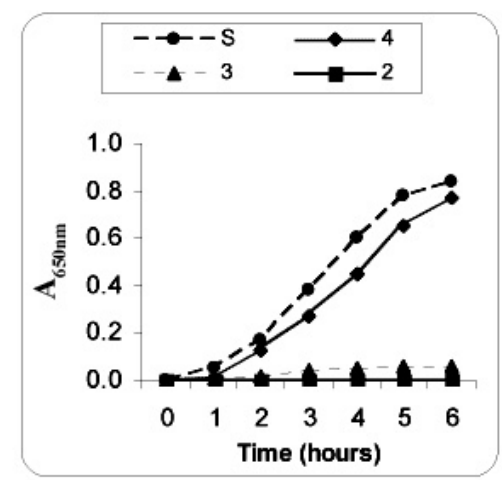

(11)

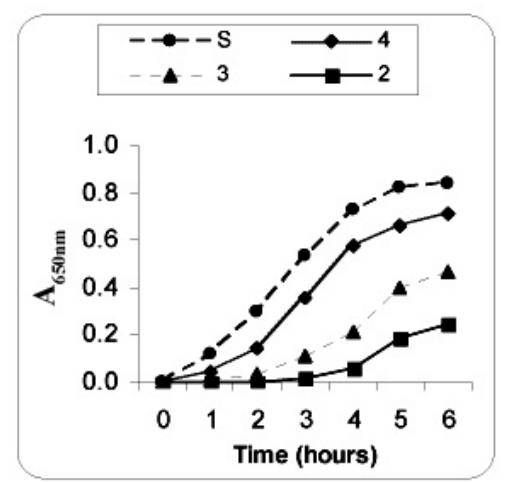

(3)

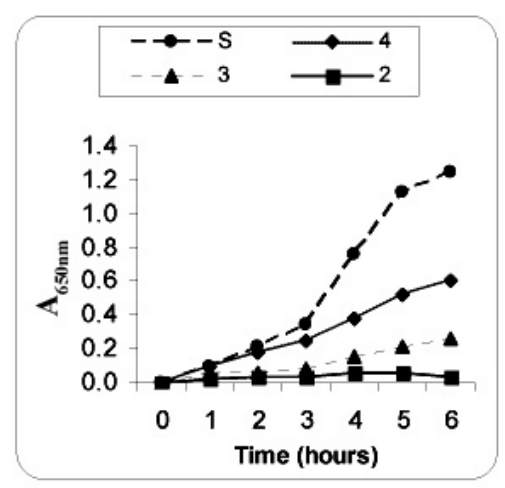

(6)

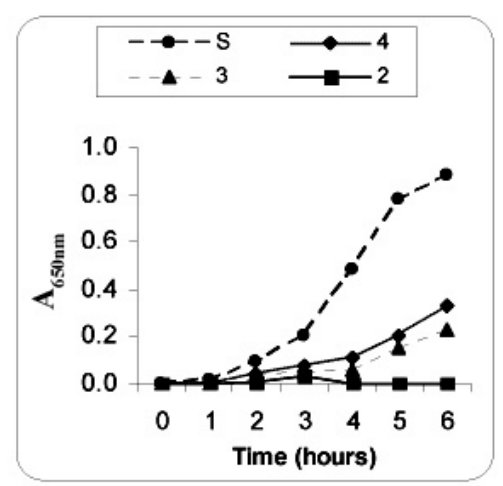

(9)

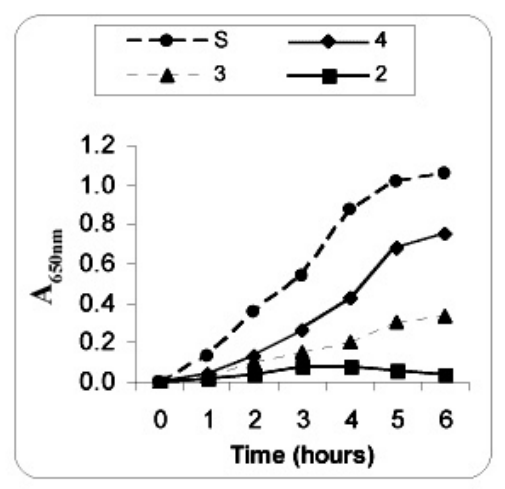

(12)

Fig. 3: Growth development of $L b$. fermentum $(1,2,3,4,5,6,7,8,9,10,11$ and 12$)$ in standard and acidified MRS broth for $6 \mathrm{hrs}$ at $37^{\circ} \mathrm{C}$ 


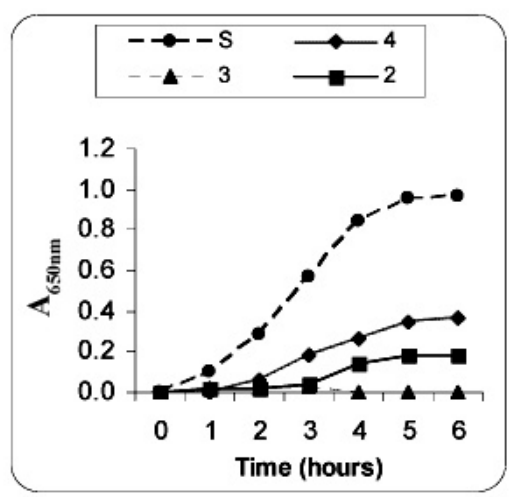

(1)

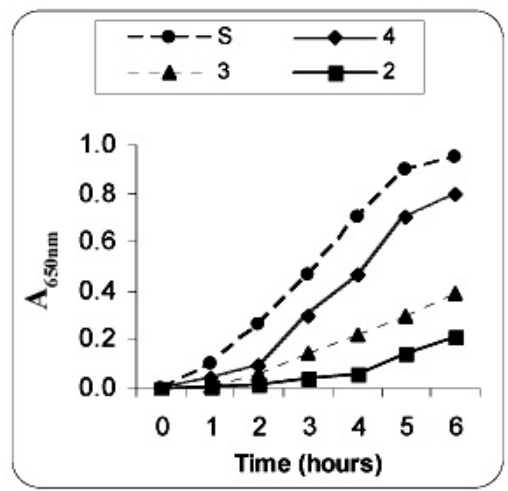

(4)

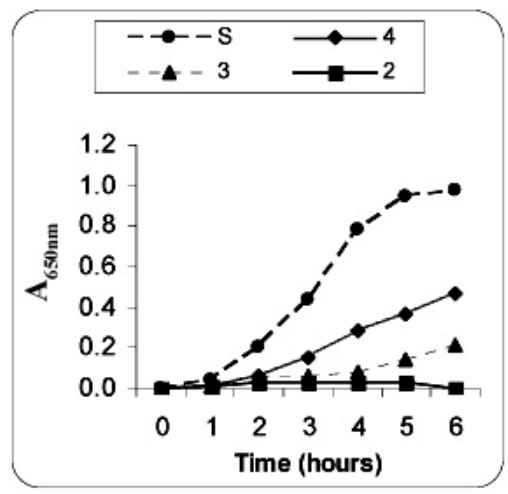

(7)

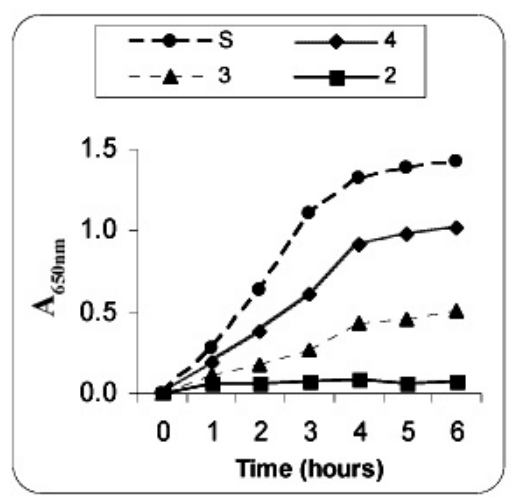

(2)

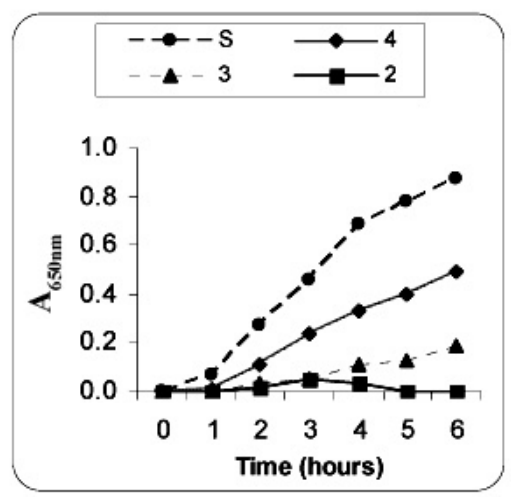

(5)

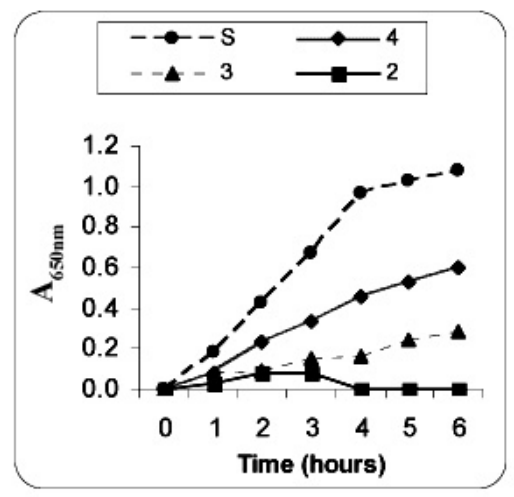

(8)

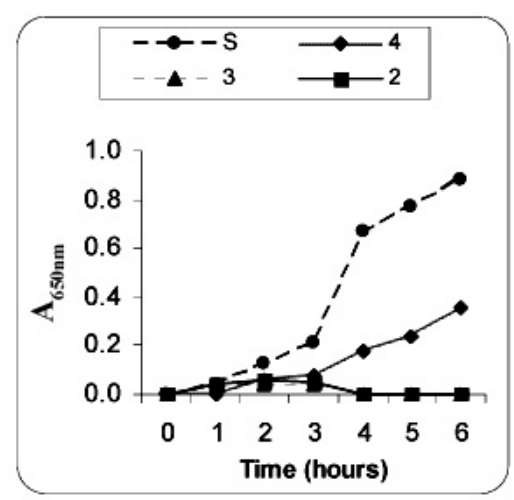

(3)

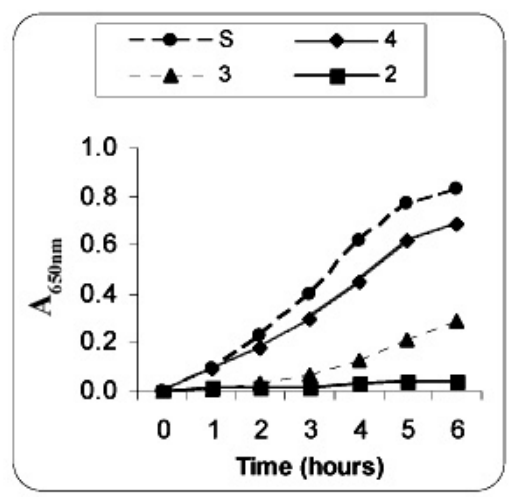

(6)

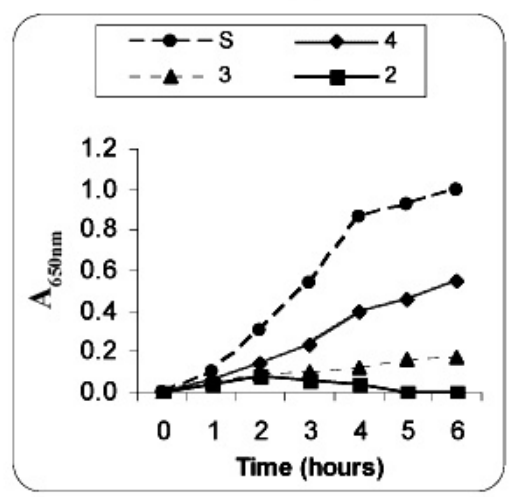

(9)

Fig. 4: Growth development of $L b$. salivarius $(1,2,3,4,5,6,7,8$ and 9) in standard and acidified MRS broth for $6 \mathrm{hrs}$ at $37^{\circ} \mathrm{C}$ 
$(2,3,5,6,7,9,10,11$ and 12) were more tolerant to the changing in $\mathrm{pH}$ than the previous group. Viability could be measured at $\mathrm{pH} 4.0$ and 3.0. Lb. fermentum (1, 4 and 8 ) were the most tolerant strains to changes of $\mathrm{pH}$ values. These results are in agreement with those reported by Pereira \& Gibson (2002) who reported that human isolates of $\mathrm{Lb}$. fermentum were able to maintain viability at $\mathrm{pH} 2$.

The results in Fig. (4) demonstrate that Lb. salivarius (3) was less sensitive strain to low $\mathrm{pH}$, the culture could not grow at $\mathrm{pH} 3.0$ and 2.0 at $37^{\circ} \mathrm{C}$. While, Lb. salivarius (1, 2, 5, 6, 7, 8 and 9) were more tolerant to the changing $\mathrm{pH}$. Viability could be measured at $\mathrm{pH} 4.0$ and 3.0. Lb. salivarius (4) was the most tolerant strain to changes of $\mathrm{pH}$ values. This result was in agreement with Rönkä et al. (2003).

In conclusion, Lactobacilli of intestinal origin are considered intrinsically resistant to acid environments and are often employed in fermented foods as probiotics (Cocoran et al. 2005). Probiotic tests conducted on Lb. fermentum indicated its potential as good probiotic candidate tolerate the gastrointestinal tract acid and bile conditions. These results are in accordance with those previously reported by Pereira \& Gibson (2002) and Pereira et al. (2003). Moreover, they found that no undesirable microbial-metabolic characteristics have been caused which could hamper its use as a probiotic for human consumption.

\section{ACKNOWLEDGMENT}

This research was supported by grant received from the US.-Egypt Board on Scientific and Technological Cooperation. The fund was established under an agreement between the government of the United States of America and the Government of the Arab Republic of Egypt on Science and Technology Cooperation. The authors wish to thank the research team involved with the project for their hard work and devotion.

\section{REFERENCES}

Berrada, N., Lemeland, J.F., Laroch, G., Thouvenot, P. \& Piaia, M. 1991. Bifidobacterium from fermented milks: survival during gastric transit. Journl Dairy Scince, 74:409-413.

Brashears, MM., Jaroni, D. \& Trimble, J. 2003. Isolation, selection and characterization of lactic acid bacteria for a competitive exclusion product to reduce shedding of Escherichia coli O157:H7in cattle. Journal Food Protection, 66: 355-363.

Charteris, W.P., Kelly, P.M., Morelli, L. \& Collins, J.K. 1998 .Development and application of an in vitro methodology to determine the transit tolerance of potentially probiotic Lactobacillus and Bifidobacterium species in the upper human gastrointestinal tract. Journal of Applied. Microbiology, 84:759-768.

Cocoran, B.M., Stanton, C., Fitzgerald, G.F. \& Ross, R.P. 2005. Survival of probiotic lactobacilli in acidic environments is enhanced in the presence of metabolized sugars. Applied Environment Microbiology, 71: 3060-3067.

Gilliland, S.E., Stanley, T.E. \& Bush, L.J. 1984. Importance of bile tolerance of Lactobacillus acidophilus used as a dietary adjunct. Journal Dairy Science, 67: 3045-3051.

Gilliland, S.E. 1987. Importance of bile tolerance in lactobacilli used as dietary adjunct. In: Biotechnology in the Feed Industry, (Lyons, T. P., Ed.), p.149-155. Alltech Feed Co., Lexington, $\mathrm{KY}$.

Goldin, B.R. \& Gorbach, S.L. 1989. Lactobacillus strain and methods of selection, US Patent ,4: 839, 281.

Hirayama, K. \& Rafter, J. 2000. The role of probiotic bacteria in cancer prevention. Microbes Infection, 2: 681-686.

Kim, W.S., Ren, J. \& Dunn, N.W. 1999. Differentiation of Lactococcus lactis subspecies lactis and subspecies cremoris strains by their adaptive response to stresses. FEMS Microbiology Letters. 171: 57-65.

Ouwehand, A.C., Kirjavinen, P.V., Shortt, C. \& Salminen, S. 1999. Probiotics: mechanisms and established effects. International Dairy Journal, 9: 43-52.

Lankaputhra, W.E.V. \& Shah, N.P. 1995. Survival of Lactobacillus acidophilus and Bifidobacterium spp. in the presence of acid and bile salts. Cult. Dairy Prod. Journal, 30: 2-7.

Marteau, P., Pochart, P., Bouhnik, Y. \& Rambaud, J.C. 1993. Fate and effects of some transiting microorganisms in the human gastrointestinal tract. World Rev. Nutrition Diet, 74: 1-21.

Olejnik, A., Lewandowska, M., Obarska M. \& Grajek, W. 2005. Tolerance of Lactobacillus 
and Bfidobacterium strains to low $\mathrm{pH}$, bile salts and digestive enzymes. Electronic journal of Polish Agricultural Universities, Food Science and Technology, 8:1-5.

Pereira, D.I.A. \& Gibson, G.R. 2002. Cholesterol assimilation by lactic acid bacteria and bifidobacteria isolated from the human gut. Applied Environment Microbiology, 68: 46-89.

Pereira D.I., McCartney AL. \& Gibson, G.R. 2003. An in vitro study of the probiotic potential ofa bile salt hydrolyzing Lactobacillus fermentum strain, and determination of its cholesterol-lowering properties. Applied Environment Microbiology, 69: 4743-4752.

Rafter, J.J. 2002. Scientific basis of biomarkers and benefits of functional foods for reduction of disease risk: cancer. Br. Journal Nutrition, 88: S219-224.
Renault, P. 2002. Genetically modified lactic acid bacteria: applications to food or health and risk assessment. Biochimie, 84: 1073-1087.

Robinson, R.K. 1987. Survival of Lactobacillus acidophilus in fermented products. Suid Afrikaanse Tydskrif Vir Suiwelkunde, 19: 25-27.

Rönkä, E., Malinen, E., Saarela, M., Rinta-Koski, M., Aarnikunnas, J. \& Palva, A. 2003. Probiotic and milk technological properties of Lactobacillus brevis. International Journal of Food Microbiology, 83: 63-74.

Saarela, M., Mogensen, G., Fonden, R., Matto, J. \& Mattilasandholm, T. 2000. Probiotic bacteria: safety, functional and technological properties. Journal Biotechnolgy, 84: 197-215.

Shah, N.P. 2000. Probiotic bacteria: selective enumeration and survival in dairy foods. Journal Dairy Science, 83: 894-907.

\footnotetext{
تأثــير أمـلاح الصفـراء والحموضـهـ على حيويـة بعضض بكتريـا حامضض اللاكتيـك

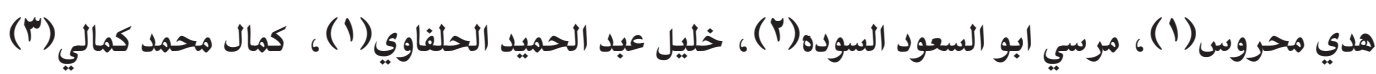

(1) معهد الهذدسة الوراثية - جامعة المنوفية.

(r) كلية الزراعة - جامعة الاسكندرية.

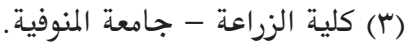

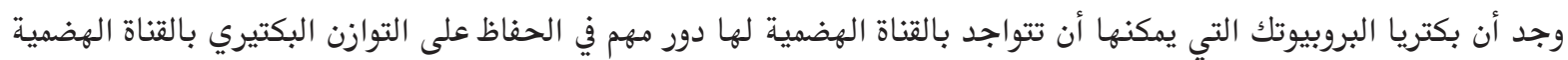

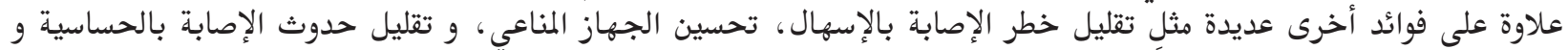

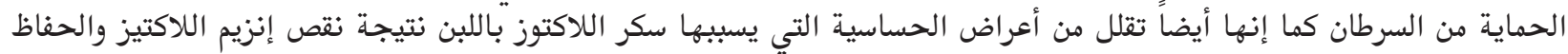
على حركة الأمعاء بصورة طبيعية.

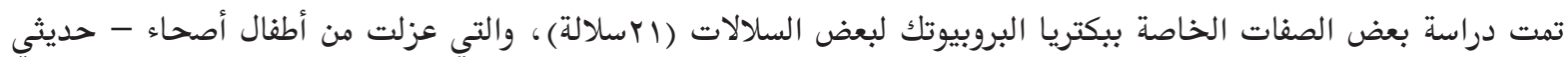

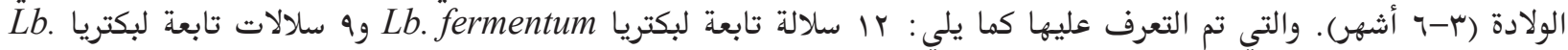
البقاء حئة salivarius

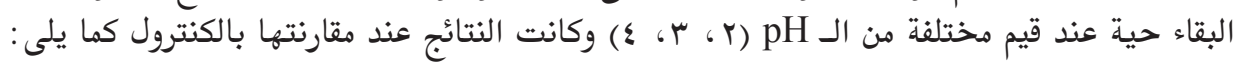

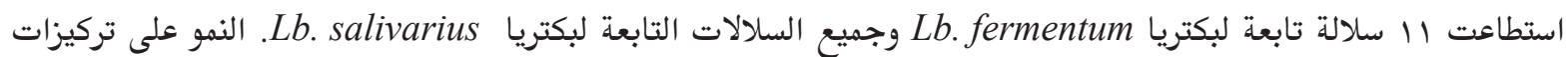

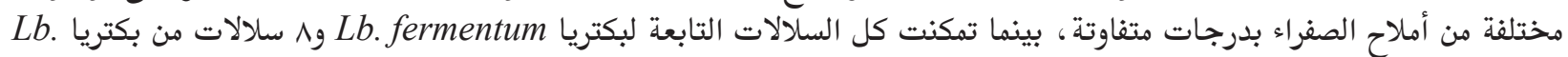
مalivarius
} 